\title{
IMPLEMENTASI PENGELOLAAN PAJAK RETRIBUSI PARKIR DI KOTA KENDARI
}

\author{
Oleh:
}

\author{
La Ode Mustafa' ${ }^{1}$ La Ode Muhammad Elwan ${ }^{2}$ \\ ${ }^{1,2}$ Dosen Fakultas Ilmu Sosial dan Ilmu Politik Universitas Halu Oleo \\ laodemustafa@uho.ac.id, muh.elwan@uho.ac.id
}

\begin{abstract}
The purpose of this study was to determine the management of parking levy taxes and efforts made by Kendari City government in optimizing the receipt of parking tax / retribution in Kendari City.

The research method used is a qualitative research method with a descriptive analysis approach, data collection using interview, observation and documentation techniques. The data analysis technique used by the author is a qualitative data analysis technique that is by searching and compiling systematically from the results of interviews, observation and documentation then selecting the data needed and making conclusions that are easy to understand.

Based on the results of the study, the management of parking fees that have been carried out so far has been quite good, can be seen from the percentage between the target and the realization of parking retribution from 20162018 experiencing fluctuations and in 2017 did not reach the target set, and the last 3 (three) years this contribution of parking fees to local original income is very small. This is because there are still many obstacles experienced by the Regional Tax and Retribution Management Agency in Kendari in managing parking fees. In the planning process has been going well can be seen in determining the target parking retribution per year which always refers to the results of the evaluation of the achievement of targets in the previous year and see the potential in the field. Organizing is still not effective, it can be seen from the standard of work of the parking fees officers still experiencing obstacles in the number of personnel. From the implementation efforts, it is still not effective in collecting parking taxes, such as the provision of parking permits, there are still some who do the installation without making prior permission and lack of awareness of the taxpayer about the importance of paying taxes which is the foundation for Kendari City Development. Only the supervision indicators carried out by superiors to subordinates are effective, such as monitoring carried out to evaluate the work is maximized, so as not to provide opportunities for individuals in the field to commit fraud. But supervision of the community is still not effective because there are still many illegal parking lots without having installation permits.
\end{abstract}

\section{Keywords : Tax management, Parking fees}


Vol.1 No.4. Januari 2019. pp.18-31. Copyright@2019 PUBLICUHO Faculty of Social and Political Sciences Halu Oleo University, Kendari, Southeast Sulawesi, Indonesia. ISSN: 2460-058X | e-ISSN: 2621-1351. Open Access at: http://ojs.uho.ac.id/index.php/PUBLICUHO

Jounal publiuho is licensed under a Creative Commons Attribution 4.0 International License, which permits unrestricted use, distribution, and reproduction in any medium, provided the original work is properly cited.

\section{PENDAHULUAN}

Pembiyaan pembagunan selalu menjadi faktor penentu dalam pelaksanaan pembangunan. Membangun berarti memberikan yang terbaik bagi seluruh masyarakat melalui pemenuhan kebutuhan akan pelayanan dan kebutuhan hidup warganya. Kondisi tersebut dapat terpenuhi jika pemerintah serius untuk memperhatikan apa yang menjadi kebutuhan masyarakat secara keseluruhan bukan secara parsial. Olehnya itu, di dalam merencanakan, mengornaisasi, mengaktualisasi dan mengawasi proses pembangunan menjadi wajib bagi pemerintah untuk di implementasikan dalam kehidupan berbangsa dan bernegara dengan visi mensejahterakan masayarakatnya.

Sejauh ini, proses pembangunan terhambat akibat dari minimnya pembiayaan atau anggaran pembangunan akibat dari kurangnya pendapatan negara dan atau pendapatan daerah dalam pelaksanaan pembangunan. Maka solusinya adalah, bagaimana pemerintah dapat memperoleh sumber-sumber pendapatan melalui pajak, restribusi, sumbangan dan kerjasama antar pihak-pihak berkepentingan.

Menurut Ginandjar Kartasasmita (1996 : 335), pembangunan daerah bertujuan meningkatkan taraf hidup dan kesejahteraan rakyat di daerah melalui pembangunan yang serasi dan terpadu baik antar sektor maupun antar pembangunan sektoral dengan perencaan pembangunan oleh daerah yang efektif menuju tercapainya kemandirian daerah yang merata di seluruh pelosok tanah air.

Kondisi ini di pertegas dalam peraturan tentang pembagian daerah tercantum dalam Pasal 18 Undang-Undang Dasar 1945 yang berbunyi: "Pembagian daerah atas daerah besar dan kecil, dengan bentuk susunan pemerintahannya ditetapkan dalam Undang-undang, dengan memandang dan mengingat dasar permusyawaratan dalam sistem pemerintahan Negara dan hak-hak asal usul dalam daerah-daerah yang bersifat istimewa". Pemerintah Indonesia memahami dalam memajukan negaranya, telah mengambil keputusan untuk memberikan otonomi daerah yaitu dimana pemerintah daerah dapat mengatur daerahnya masing-masing. Keputusan yang diambil pemerintah Indonesia supaya dapat lebih memajukan daerahnya, pemerintah pusat sebagai pengawas dan memberikan subsisdi untuk pembangunan daerah.

Upaya dalam peningkatan kontribusi dana antara daerah yang satu dengan yang lainnya dilakukan sesuai kondisi daerah yang bersangkutan. Disamping itu penyelenggaran otonomi daerah dilaksanakan dengan prinsip-prinsip demokrasi, peran serta masyarakat, pemerataan dan berkeadilan serta memperhatikan potensi dan keanekaragaman daerah. (Deddy SB \& Dadang Solihin, 2001 : 1).

Pembangunan berakhlak menjadi penting di kembangkan di setiap daerah. Dengan begitu setiap daerah bertanggung jawab dalam menggali kemampuan sumber-sumber keuangan lebih tinggi untuk mengelola dan mengurusi rumah tangganya sendiri termasuk mengelola sumber-sumber penerimaan daerah. Sumber-sumber penerimaan tersebut digunakan untuk mendukung meningkatkan Pendapatan Asli Daerah.

Menurut Ahmad Yani (2008 : 51), pendapatan Assli Daerah (PAD) merupakan pendapatan yang bersumber dari hasil pajak daerah, hasil retribusi daerah, hasil pengelolaan kekayaan daerah yang dipisahkan dan pendapatan lain asli daerah yang sah, yang bertujuan untuk memberikan kekuasaan kepada daerah dalam menggali pendanaan dalam pelaksanaan otonomi daerah sebagai wujud asas desentralisasi.

Untuk meningkatkan sumber-sumber pendapatan asli daerah, maka perlu adanya mencapai pelayanan dan pelaksanaan pembangunan secara efektif dan efisien dalam mendukung sumber pembiayaan daerah dalam menyelenggarkan pembangunan daerah. Sehingga pemerataan perekonomian serata kesejahteraan masyarakat. Pemerintah sebagai pemimpin suatu wilayah harus bertanggung jawab akan semua yang ada. Selain itu 
pemerintahan harus dekat dan dicintai rakyatnya sehingga keluhan-keluhan rakyat akan didengar dengan mudah.

Salah satu sumber penerimaan yang menjadi andalan daerah antara lain berasal dari sektor retribusi selain pajak. Penerimaan yang bersumber dari sektor retribusi mempunyai potensi yang cukup besar sehingga dibutuhkan upaya untuk dapat meningkatkan penerimaan. Disisi lain, berkaitan dengan peningkatan penerimaan retribusi perlu dibarengi dengan penyediaan fasilitas sarana dan prasarana serta penyediaan pelayanan yang berkualitas. Penerimaan retribusi daerah didasarkan atas ketentuan yang tercantum dalam Undang-Undang Nomor 18 Tahun 1997 yang kemudian dirubah dengan Undang-Undang Nomor 34 Tahun 2000, tentang Pajak Daerah dan Retribusi Daerah. Peraturan pelaksanaannya tertuang pada Peraturan Pemerintah Republik Indonesia Nomor 65 Tahun 2001 tentang Pajak Daerah, untuk kemudian disempurnakan lagi dengan Undang-Undang Nomor 28 Tahun 2009, tentang Pajak daerah dan Retribusi. Pelaksanaannya diatur dalam Peraturan Pemerintah Republik Indonesia Nomor 66 Tahun 2001 tentang Retribusi Daerah yang kemudian disempurnakan lagi dengan Peraturan Pemerintah Nomor 97 Tahun 2012, tentang Retribusi Pengendalian Lalu Lintas dan Retribusi Perpanjangan Izin Tenaga Kerja Asing. Kemudian oleh Pemerintah daerah menuangkannya dalam Peraturan Daerah tentang Retribusi. Dalam ketentuan tersebut, retribusi daerah adalah pungutan daerah sebagai pembayaran atas jasa atau pemberian izin tertentu yang khususnya disediakan dan atau diberikan oleh Pemerintah Daerah untuk kepentingan orang pribadi atau badan.

Sebagai salah satu jenis pungutan yang berpotensi memberikan kontribusi terhadap peningkatan Pendapatan Asli Daerah, penerimaan retribusi berkaitan dengan manajemen pengelolaannya yang didukung oleh penyediaan fasilitas dan jasa yang disediakan oleh Pemerintah Daerah kepada masyarakat berupa pembangunan terminal angkutan umum lengkap dengan ruang tunggu penumpang yang datang dan pergi.

Penyediaan fasilitas sarana tersebut selain dalam rangka meningkatkan penerimaan retribusi parkir juga berkaitan secara langsung maupun tidak langsung dengan kemudahan para pemangku kepentingan untuk memperoleh pendapatan yang memadai. Upaya lain untuk meningkatkan penerimaan restribusi parkir yang secara langsung dapat merangsang stakeholders yaitu, pembangunan prasarana jalan, jembatan, yang memungkinkan kelancaran beroperasinya kendaraan melakukan aktivitasnya. Dengan tersedianya sarana dan prasarana yang memadai memungkinkan para stakeholders dapat memperoleh pendapatan yang memadai, dan pada gilirannya berimbas pada meningkatnya penerimaan retribusi. Di sisi lain, kelancaran operasional kendaraan mendorong masyarakat untuk menggunakan kendaraanya dalam melakukan aktivitasnya.

Berdasarkan obervasi awal di lapangan, kebijakan pengelolaan pajak restribusi parkir untuk menunjang belum mampu meningkatkan pendapatan dari sektor retribusi parkir di Kota Kendari. Target yang ditetapkan setiap tahun masih mengalami pasang surut dan belum mampu mencapai 100 persen. Data tiga tahun terkahir penerimaan retribusi di Kota Kendari, menggambarkan tingkat pencapaian target tahun 2016 hanya mampu mencapai 86,04\%. Tahun 2017 penerimaan retribusi menurun drastis hingga mencapai 55,47\%. Tahun 2018 hanya mengalami kenaikan sedikit dari tahun 2017 yaitu sebesar 58,33\%. Data tersebut menunjukan bahwa, pajak retribusi parkir sebagai salah satu sub sektor sumber penerimaan daerah, belum dapat diandalkan untuk meningkatkan Pendapatan Asli Daerah. Data tersebut menunjukan bahwa, pajak retribusi parkir sebagai salah satu sub sektor sumber penerimaan daerah, belum dapat diandalkan untuk meningkatkan Pendapatan Assli Daerah.

Kondisi ini sudah tentu sangat memprihatinkan mengingat besarnya anggaran yang digunakan untuk menyediakan fasilitas sarana dan prasarana angkutan umum. Permasalahan pelaksanaan fungsi perencanaan, pengorganisasian, penggerakkan dan pengawasan dalam rangka pencapaian target penerimaan restribusi parkir, belum mempertimbangkan kondisi obyektif dilapangan, dengan menyajikan pilihan-pilihan alternatif 
Vol.1 No.4. Januari 2019. pp.18-31. Copyright@2019 PUBLICUHO Faculty of Social and Political Sciences Halu Oleo University, Kendari, Southeast Sulawesi, Indonesia. ISSN: 2460-058X | e-ISSN: 2621-1351. Open Access at: http://ojs.uho.ac.id/index.php/PUBLICUHO

Jounal publiuho is licensed under a Creative Commons Attribution 4.0 International License, which permits unrestricted use, distribution, and reproduction in any medium, provided the original work is properly cited.

yang terbaik. Selain itu, pimpinan organisasi atau instansi pemerintah yakni Badan Pengelola Pajak dan Restribusi Daerah Kota Kendari ebagai penanggungjawab teknis dan operasional belum maksimal mengarahkan pegawai dan petugas secara baik dan memastikan mereka mengetahui apa yang harus dilakukan, serta membantu mengembangkan keterampilan-keterampilannya. Dalam menggerakkan petugas dilapangan, belum ada upaya untuk mengembangkan bagaimana agar pegawai dan petugas lapangan bersedia memberikan segala-galanya dan bukan sekedar bekerja asal jadi. Demikian halnya dengan fungsi pengawasan kurang optimal dalam membantu pegawai dan petugas lapangan menentukan kemajuan menuju ke arah sasaran yang harus dicapai. Berdasarkan penjelasan diatas maka penulis tertarik menggali lebih dalam mengenai "Implementasi pengelolaan pajak retribusi parkir di Kota Kendari dengan fokus studi pada Badan Pengelola Pajak dan Restribusi Daerah Kota Kendari".

\section{TINJAUAN PUSTAKA}

\section{Konsep Pengelolaan}

Menurut Amirullah (2015 : 5), pengelolaan merupakan terjemahan dari kata "management", yang artinya manajemen. Manajemen berasal dari kata to manage yang artinya mengatur, pengeturan dilakukan melalui proses dan diatur berdasarkan urutan dari fungsi-fungsi manajemn. Jadi manajemen itu merupakan suatu proses untuk mewujudkan tujuan yang di inginkan melalui aspek-aspeknya antara lain planning, organizing, actuating, dan controling. Lebih jauh, Suharsimi Arikunto (1988 : 8), menjelaskan bahwa pengelolaan adalah subtansi dari mengelola, sedangkan mengelola berarti suatu tindakan yang dimulai dari penyususnan data, merencana, mengorganisasikan, melaksanakan, sampai dengan pengawasan dan penilaian. Dijelaskan kemudia pengelolaan menghasilkan suatu dan sesuatu itu dapat merupakan sumber penyempurnaan dan peningkatan pengelolaan selanjutnya.

Marry Parker Follet (2005 : 58) mendefinisikan pengelolaan adalah seni atau proses dalam menyelesaikan sesuatu yang terkait dengan pecapaian tujuan. Dalam penyelesaian akan sesuatu tersebut, terdapat tiga faktor yang terlibat yakni l) adanya penggunaan sumber daya organisasi, baik sumber daya manusia maupun faktorfaktor produksi lainya. 2) Proses yang bertahap mulai dari perencanaan, pengorganisasian, pengarahan dan pengimplementasian, hingga pengendalian dan pengawasan. 3) Adanya seni dalam penyelesaian pekerjaan.

Jadi dapat disimpulkan bahwa pengelolaan (manajemen) adalah suatu cara atau proses yang dimulai dari perencanaan, pengorganisasian, pengawasan dan evaluasi untuk mencapai suatu tujuan yang telah ditentukan agar berjalan efektif dan efisien.

\section{Fungsi Pengelolaan}

Banyak sekali fungsi manajemen, tapi dapat ditarik kesimpulan dari pendapat para ahli ada empat fungsi yang sama yakni perencanan, pengorganisasian, pengarahan dan pengawasan. Adapun penjelasan dari fugsi-fungsi tersebuat adalah :

\section{Perancanaan (Planning)}

Menurut M. Manulang (1990 : 15), perencanaan merupakan pemilihan dan penghubungan fakta, menguatkan asumsi-asumsi tentang masa depan dalam membuat visualisasi dan perumusan kegiatan yang diusulkan dan memang diperlukan untuk mencapai hasil yang diinginkan. Perencanaan mencakup kegiatan pengambilan kepeutusan, karena termasuk pemilihan alternatif-alternatif kepuasan. Diperlukan kemampuan untuk mengadakan visualitas dan melihat ke depan guna merumuskan suatu pola dari himpunan tindakan untuk masa mendatang. 


\section{Pengorganisasian (Orginizing)}

Pengorganisasian adalah keseluruhan proses pengelompokan orang-orang, alat-alat, tugas-tugas tanggung jawab dan wewenang sedemikian rupa sehingga tercipta suatu organisasi yang dapat digerakkan sebagai suatu kesatuan dalam rangka pencapaian tujuan yang telah ditetapkan (M. Manulang, 1990 : 18).

\section{Pelaksanaan (Actuating)}

Menurut Susilo Martoyo (1998 : 89), pelaksanaan atau juga biasa didefinisikan sebagai segala tindakan untuk menggerakkan orang-orang dalam suatu organisasi, agar dengan kemauan dengan penuh berusaha mencapai tujuan organisasi dengan berlandaskan pada perencanaan dan pengorganisasian. Penggerakan mencakup penetapan dan pemuasan kebutuhan manusiawi dari pegawai-pegawainya, memberi penghargaan, memimpin, mengembangkan dan memberi kompensasi kepada mereka. actuating atau juga disebut" gerakan aksi " mencakup kegiatan yang dilakukan seorang manajer untuk mengawali dan melanjutkan kegiatan yang ditetapkan oleh unsur-unsur perencanaan dan pengorganisasian agar tujuan-tujuan dapat tercapai.

\section{Pengawasan (Contolling)}

Menurut Henry Fayol dalam Sofyan Syafri (1996 : 282), pengawasan merupakan pemeriksaan apakah semua yang terjadi sesuai dengan rencana yang ditetapkan, intruksi yang dikeluarkan sesuai dengan prinsip yang telah ditetapkan.

\section{Konsep Pajak Daerah}

Berdasarkan kewenangan pemungutannya, di Indonesia pajak dapat dibagi menjadi pajak pusat dan pajak daerah. Pajak daerah merupakan pajak yang dikelola oleh pemerintah daerah, baik Provinsi maupun Kabupaten atau kota yang berguna untuk menunjang penerimaan pendapatan asli daerah dan hasil penerimaan tersebut masuk dalam APBD (Kurniawan, 2006 : 47).

Secara detil, Pajak daerah menurut Undang Undang Nomor 28 Tahun 2009 adalah kontribusi wajib kepada daerah yang terutang oleh orang pribadi atau badan yang bersifat memaksa berdasarkan Undang- Undang, dengan tidak mendapatkan imbalan secara langsung dan digunakan untuk keperluan daerah bagi sebesarbesarnya untuk kemakmuran rakyat.

Menurut Marihot Siahaan (2010 : 247), pajak kabupaten atau kota yang diatur dalam Undang-Undang Nomor 28 Tahun 2009 (PDRD) adalah sebagai berikut: Pajak Hotel, Pajak Restoran, Pajak Hiburan, Pajak Reklame, Pajak Penerangan Jalan, Pajak Mineral Bukan Logam dan Batuan, Pajak Parkir, Pajak Bumi dan Bangunan Perdesaan serta Perkotaan, dan Bea Perolehan Hak atas Tanah dan Bangunan.

Dalam UU PDRD tersebut ada sebuah ketentuan terkait dengan jenis pungutan yang dapat diberlakukan disetiap daerah. Pemerintah daerah Kabupaten atau kota hanya dapat melakukan pungutan pada masyarakat, apabila jenisnya telah tecantum dalam UU PDRD. Pembatasan jumlah pungutan ini yang dikenal dengan istilah close list (daftar tertutup).

\section{Konsep Retribusi Daerah}

Penerimaan pemerintah daerah selain dari pajak daerah dan bagi hasil pajak pusat yang diperuntukkan ke pemerintah daerah berasal dari retribusi daerah. Akan tetapi, untuk retribusi tiap daerah memiliki potensi yang berbeda satu sama lain, untuk itu pemerintahan daerah harus dapat melihat peluang apa saja yang dapat dilakukan dalam menggali penerimaan dari retribusi untuk menunjang penerimaan.

Menurut Marihot Siahaan (2010 : 15), terdapat beberapa ciri yang melekat pada retribusi daerah yang saat ini dipungut di Indonesia adalah sebagai berikut : 
Vol.1 No.4. Januari 2019. pp.18-31. Copyright@2019 PUBLICUHO Faculty of Social and Political Sciences Halu Oleo University, Kendari, Southeast Sulawesi, Indonesia. ISSN: 2460-058X | e-ISSN: 2621-1351. Open Access at: http://ojs.uho.ac.id/index.php/PUBLICUHO

Jounal publiuho is licensed under a Creative Commons Attribution 4.0 International License, which permits unrestricted use, distribution, and reproduction in any medium, provided the original work is properly cited.

1) Retribusi merupakan pungutan yang dipungut berdasarkan Undang- Undang dan Peraturan Daerah yang berlaku;

2) Hasil penerimaan retribusi masuk ke kas pemerintah daerah. Pihak yang membayar retribusi mendapatkan kontraprestasi (balas jasa) secara langsung dari pemerintah daerah atas pembayaran yang dilakukannya;

3) Retribusi terutang apabila ada jasa yang diselenggarakan oleh pemerintah daerah yang dinikmati oleh orang atau badan;

4) Sanksi yang dikenakan pada retribusi adalah sanksi secara ekonomis, yaitu jika tidak membayar retribusi, tidak akan memperoleh jasa yang diselenggarakan oleh pemerintah daerah.

\section{Konsep Pajak Retribusi}

Menurut UU No.28 Tahun 2007 Pasal 1 Tentang Ketentuan Umum dan Perpajakan, pajak merupakan suatu konstribusi wajib kepada negara yang terhutang oleh setiap orang maupun badan yang sifatnya memaksa namun tetap berdasarkan pada Undang-Undang, dan tidak mendapat imbalan secara langsung serta digunakan untuk kebutuhan negara juga kemakmuran rakyatnya. Menurut Rochmat Soemitro (2011 : 28), pajak ialah iuran rakyat kepada negaranya berdasarkan Undang-Undang atau peralihan kekayaan dari sektor swasta kepada sektor publik yang bisa dipaksakan dan yang langsung dapat ditunjuk serta digunakan untuk membiayai kebutuhan atau kepentingan umum.

Menurut bahasa Retribusi adalah bagian jalan bersebelahan dengan jalur gerak untuk akomodasi kendaraan yang berhenti, untuk penggunaan darurat dan untuk penyangga lateral dasar dan permukaan bahu. Namun dari persfektif Pajak Retribusi parkir yang dimaksud adalah kontribusi atau iuran masyarakat pemilik mobil angkutan dan barang dalam menggunakan jalan raya sebagai akses dalam menjalankan aktivitas mereka.

Berdasarkan hal tersebut maka, Pajak Retribusi Parkir yang dimaksud dalam penelitian ini adalah sejumlah nilai uang yang harus dibayarkan oleh para pemgguna parkir yang melakukan aktivitas ekonomi dalam menggunakan jalan raya dan area parkir tersebut seperti mobil pribadi, angkutan umum dan angkutan barang dari dalam kota maupun luar kota. Harapannya adalah pajak restribusi parkir tersebut dapat menjadi sumber pendapatan daerah dalam pembiyaan pembangunan.

\section{METODE PENELITIAN}

Artikel ini merupakan hasil penelitian yang dilaksanakan di Kota Kendari dengan fokus penelitian pada Badan Pendapatan dan Pengelolaan Pajak dan Retribusi Daerah Kota Kendari dengan pertimbangan bahwa tempat tersebut merupakan instansi teknis yang melaksanakan fungsi pengelolaan Pajak Retribusi Parkir di Kota Kendari.

Berdasarkan permasalahan yang diteliti, maka jenis penelitian yang dipergunakan adalah penelitian kualitatif. Penelitian kualitatif merupakan penelitian yang berhubungan dengan ide, persepsi, pendapat, kepercayaan orang yang akan diteliti dan itu semua tidak dapat diukur dengan angka. Data yang di hasilkan dalam penelitian ini adalah data deskriptif berupa kata-kata tertulis atau lisan dari orang-orang yang betul-betul memahami permasalahan ini. Penelitian ini menggunakan pendekatan deskriptif analisis yang ingin menjelakan secara utuh mengenai Implementasi Pengelolaan Pajak Restribusi Parkir di Kota Kendari. 


\section{Informan Penelitian}

Yang dijadikan informan penelitian ini adalah Pegawai pada Badan Pengelola Pajak dan Retribusi Daerah Kota Kendari yang terdiri dari Kepala badan, sekretaris dan staft, petugas teknis di lapangan, pengguna parkir yang seluruhnya berjumlah 9 orang.

\section{Jenis dan Sumber data}

Terdapat 2 jenis data yang akan digunakan dalam penelitian ini. Data primer, yaitu sejumlah data yang ata keterngan yang secara langsung diperoleh melalui penelitian di lapangan dalam bentuk wawancara, meliputi keterangan dari orang-orang yang diteliti yang berhubungan dengan obyek penelitian. Data sekunder adalah data-data yang didapat dari sumber seperti foto-foto dan dokumen-dokumen lainnya yang terkait dalam penelitian ini serta melalui media lain yang bersumber dari literatur seperti arsip, notulen dan rapat.

Sumber data dalam penelitian kualitatif ini yaitu orang-orang yang diwawancarai berisi kata-kata dan tindakan yang diperoleh peneliti bersumber pada hasil wawancara dengan beberapa warga sebagai informasn selebihnya adalah seperti dokumentasi dan lain-lain. Dimana sumber data ini sangat diperlukan untuk memperoleh data dan informasi yang valid, akurat serta meyakinkan yang berkaitan dengan mobilisasi politik di desa Bontomatinggi. Untuk melengkapi sumber penelitian ini yaitu penggunaan foto dan rekaman sebagai sumber data di lapangan pada saat proses penelitian berlangsung dan dapat menjadi tanda bukti bahwa seseorang telah melakukan penelitian.

\section{Teknik Analisis Data}

Analisis data adalah proses mencari dan menyusun secara sistematis data hasil wawancara ,observasi dan dokumentasi dengan cara mengorganisasikan data dan memilih mana yang penting serta mana yang perlu dipelajari serta membuat kesimpulan sehingga mudah dipahami (Sugiyono, 2007: 333-345). Teknik analisis data yang digunakan dalam penelitian ini adalah analisis kualitatif yang digunakan peneliti sebagaimana yang dikemukakan Miles dan Hobberman. (Sugiyono,2007). Mengemukakan bahwa aktivitas dalam anaalisis data kualitatif dilakukan secara interaktif dan berlangsung secara terus menerus sampai tuntas, sehingga datanya sudah jenuh.

Untuk menganalisis data, peneliti menggunakan metode analisis data deskriptif kualitatif dari Milles dan Huberman (2000:20) meliputi empat komponen, diantaranya :

a) Pengumpulan data: Pengumpulan data adalah data pertama dan data mentah dikumpulkan dalam suatu penelitian

b) Reduksi data: Menurut Sugiyono (2013:247) bahwa proses berfikir sensitif yang memerlukan kecerdasan, keluasan, dan kedalaman wawasan yang tinggi. Oleh karena itu, reduksi data yang dimaksudkan dalam penelitian ini yakni proses memilih, memfokuskan, menyederhanakan dan membuat abstraksi, mengubah data mentah yang di kumpulkan melalui penelitian kedalam catatan yang telah disortir atau diperiksa.

c) Display data (Penyajian data): Data yang telah direduksi tersebut merupakan sekumpulan informasi yang kemudian disusun atau diajukan sehingga memberikan kemungkinan adanya penarikan kesimpulan dan pengambilan tindakan. Menurut Sugiyono (2013: 250), dengan display data maka akan memudahkan untuk memahami apa yang terjadi, merencanakan kerja selanjutnya berdasarkan apa yang telah dipahami tersebut.

d) Penarikan kesimpulan atau verifikasi: Menurut Sugiyono (2013: 252) verifikasi merupakan langkah terakhir meliputi makna yang telah disederhanakan, disajikan dalam pengujian data dengan cara mencatat keteraturan, pola-pola penjelasan secara logis dan metodelogis, konfigurasi yang memungkinkan dipredeksikan hubungan sebab akibat melalui hukum-hukum empiris. 
Vol.1 No.4. Januari 2019. pp.18-31. Copyright@2019 PUBLICUHO Faculty of Social and Political Sciences Halu Oleo University, Kendari, Southeast Sulawesi, Indonesia. ISSN: 2460-058X | e-ISSN: 2621-1351. Open Access at: http://ojs.uho.ac.id/index.php/PUBLICUHO

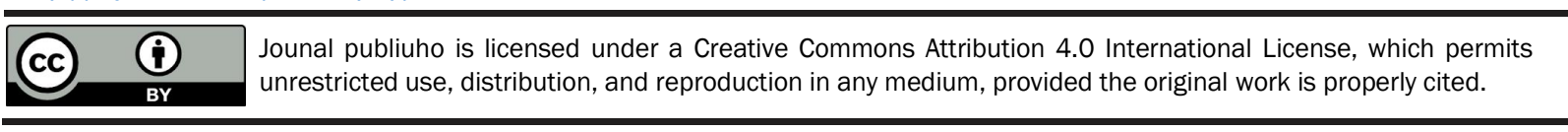

\section{PEMBAHASAN}

Pengelolaan restribusi parkir di Kota Kendari secara teknis di lakukan oleh Badan Pengelola Pajak Dan Retribusi Daerah Kota Kendari.

Banyaknya jumlah titik parkir yang di miliki pihak ke tiga (swasta) diKota Kendari membuat pemerintah Kota Kendari menjadi wajib untuk melakukan penertiban dan pengelolaan untuk menghindari adanya konflik kepentingan antar pengelola parkir.

Secara umum, jumlah titik parkir yang berada di Kota Kendari dalah berjumlah 155 titik parkir dan tersebar di beberapa lokasi kantor dan ruko dan tempat ruang publik. Jumlah yang banyak ini, tidak sebanding dengan jumlah titik parkir yang di kelolah oleh pemerintah Kota Kendari. Berikut data titik Parkir Pemerintan yang di kelola oleh swasta.

Tabel 1. Pajak Parkir Milik Pemerintah Yng Dikelola Swasta

\begin{tabular}{|c|l|l|l|l|}
\hline \multirow{2}{*}{ No } & \multirow{2}{*}{ Nama dan Jenis Usaha } & \multirow{2}{*}{ Alamat } & \multicolumn{2}{|c|}{ Keterangan } \\
\cline { 4 - 5 } & & & Kelurahan & \multicolumn{1}{|c|}{ Kecamatan } \\
\hline l & Master Parking Abunawas & Jl. Malaka & Anduonuhu & Poasia \\
\hline 2 & Master Parking PS. Baruga & Jl. Pasar Baruga & Baruga & Baruga \\
\hline 3 & Master Parking Mall Mandonga & Jl Abd. Silondae & Mandonga & Kadia \\
\hline 4 & Master Parking Lippo Plaza & Jl. MT. Haryono & Bende & Kadia \\
\hline
\end{tabular}

Sumber: Badan Pengelolaan Pajak dan Retribusi Kota Kendari 2019

Tabel 2. Retribusi Tempat Parkir

\begin{tabular}{|c|c|c|c|c|}
\hline \multirow{2}{*}{ No } & \multirow{2}{*}{ Nama dan jenis Usaha } & \multirow{2}{*}{ Alamat } & \multicolumn{2}{|c|}{ Keterangan } \\
\hline & & & Kelurahan & Kecamatan \\
\hline 1 & Peddis Market & Jl. Lawata & Punggolaka & Puuwatu \\
\hline 2 & Pasar Sentral Kota & Jl. Ir. Soekarno & Dapu-Dapura & Kendari \\
\hline
\end{tabular}

\section{Sumber: Badan Pengelolaan Pajak dan Retribusi Kota Kendari 2019}

Opsi retribusi parkir dikelola pihik ketiga masing tumpah tindih membuat Badan Pengelolaan Pajak dan Retribusi Kota Kendari pasrah. Badan Pengelolaan Pajak dan Retribusi Kota Kendari tumpah tindih penarikan retribusi dipungut oleh dinas perhungan, namun mereka tidak serta merta mengambil alih kantong-kantong parker yang pada prinsipnya tata kelola perparkiran yang sesuai juklak dan juknis. Sebelumnya pihak ketiga, retribusi yang dipungut tepi jalan dimana petugas parker untuk membedakan petugas parker liar dan resmi, tidak bisa dilihat dari seragam saja, tetapi harus dilihat dari sudut izin pemberian karcis. Secara rinci dijelaskan pada tabel 3 Struktur dan Besaran Tarif Restribusi Tempat Parkir Khusus di Kota Kendari.

Tabel 3. Struktur dan Besaran Tarif Restribusi Tempat Parkir Khusus

\begin{tabular}{|c|l|l|}
\hline No & \multicolumn{1}{|c|}{ Jenis Pelayanan } & \multicolumn{1}{|c|}{ Besarnya Tarif } \\
\hline l & $\begin{array}{l}\text { Pemakaian Pelataran Parkir Khusus Truk } \\
\text { Lokasi samping terminal Puuwatu kendari } \\
\text { a. Kendaraan bermotor roda 4 } \\
\text { b. Kendaraan Bermotor roda } 6\end{array}$ & $\begin{array}{l}\text { Rp. } 5.000, / \text { hari } \\
\text { Rp. 10.000/hari }\end{array}$ \\
\hline
\end{tabular}




\begin{tabular}{|c|c|c|}
\hline No & Jenis Pelayanan & Besarnya Tarif \\
\hline & $\begin{array}{ll}\text { c. } & \text { Kendaraan bermotor roda } 10 \\
\text { d. } & \text { Kendaraan bermotor roda } 12\end{array}$ & $\begin{array}{l}\text { Rp. 15.000/hari } \\
\text { Rp. 20.000/hari }\end{array}$ \\
\hline 2 & $\begin{array}{l}\text { Pemakaian pelataran parkir milik pemerintah Kota } \\
\text { Kendari } \\
\text { a. Rumah sakit } \\
\text { b. Pasar dan Taman Kota }\end{array}$ & $\begin{array}{l}\text { Mobil: Rp. } 2.000 / \text { hari } \\
\text { Motor: Rp. } 1.000 / \text { hari } \\
\text { Mobil: Rp. } 2.000 / \text { sekali parkir } \\
\text { Motor: Rp. } 1.000 / \text { sekali parkir }\end{array}$ \\
\hline 3 & $\begin{array}{l}\text { Pemakaian pelatarn parkir yang dikelolah oleh } \\
\text { pemerintah Kota Kendari }\end{array}$ & $\begin{array}{l}\text { Mobil: Rp. } 2.000 / \text { sekali parkir } \\
\text { Motor: Rp. } 1.000 / \text { sekali parkir. }\end{array}$ \\
\hline
\end{tabular}

Sumber: Badan Pengelolaan Pajak dan Retribusi Kota Kendari, 2019

\section{Pengelolaan Retribusi Parkir di Kota Kendari}

\section{Perencanaan}

Perencanaan merupakan langkah awal dari pelaksanaan suatu kegiatan begitupun dalam pengelolaan retribusi parkir yang dilakukan oleh Badan Pengelola Pajak Dan Retribusi Daerah Kota Kendari. Perencanaan ini dimaksudkan sebagai proses mempersiapkan secara sistematis segala kegiatan-kegiatan yang akan dilakukan untuk mencapai tujuan tertentu dengan memanfaatkan sumber-sumber yang adas upaya lebih efektif dan efisien melalui Sub Bagian Perencanaan, Keuangan dan Pelaporan yang merumuskan prosedur perencanan dan program pendapatan daerah berupa penyusunan anggaran tiap tahunnya yang mengacu pada tahun-tahun sebelumnya.

Perencanaan dalam pengelolaan retribusi parkir di Kota Kendari dilakukan dengan menentukan besarnya target yang ingin dicapai untuk satu tahun anggaran. Penentuan target pertahun dapat menjadi tolak ukur dalam menilai keberhasilan realisasi pemungutan retribusi parkir dalam kurun waktu yang ditentukan.

Adapun Mekanisme perencanaan dalam hal penentuan target sebagai berikut:

a. Sebelum menetapkan target, maka langkah awal yang dilakukan ialah memantau di lokasi yang masih akan ditetapkan sebagai lokasi.

b. Melihat hasil capaian dari penerimaan retribusi sebelumnya.

c. Melakukan pendataan ulang terhadap titik-titik lokasi yang masih kosong, karena tiap tahunnya ada perubahan lokasi disebabkan pembangunan yang baru.

d. Selain berpacu pada tahun sebelumnya, juga akan dibuat dengan pengolahan data, namun lebih cenderung pada patokan tahun sebelumnya

e. Setelah target telah ditetapkan maka akan disetujui oleh pihak- pihak yang berwenang.

Dari hasil wawancara, penulis dapat menyimpulkan bahwa perencanaan dalam hal penentuan target selalu mengacu pada potensi-potensi yang ada di lapangan yakni titik-titik kawasan retribusi parkir yang akan semakin bertambah dengan melihat perkembangan Kota Kendari. Namun target pada tahun 2018 tidak optimal 
Vol.1 No.4. Januari 2019. pp.18-31. Copyright@2019 PUBLICUHO Faculty of Social and Political Sciences Halu Oleo University, Kendari, Southeast Sulawesi, Indonesia. ISSN: 2460-058X | e-ISSN: 2621-1351. Open Access at: http://ojs.uho.ac.id/index.php/PUBLICUHO

Jounal publiuho is licensed under a Creative Commons Attribution 4.0 International License, which permits unrestricted use, distribution, and reproduction in any medium, provided the original work is properly cited.

dikarenakan tidak maksimalnya penagihan dilapangan dan kurangnya kesadaran wajib pajak untuk membayar pajak sehingga mengurangi penerimaan retribusi parkir di Kota Kendari yang menjadi sumber Pendapatan Assi Daerah. Badan Pengelola Pajak dan Retribusi Daerah Kota Kendari perlu meningkatkan sistem pendataan dan penagihan agar dapat mengoptimalkan penyelenggaraan retribusi parkir yang akan menambah penerimaan retribusi parkir dan target bisa di capai sesuai dengan yang telah ditetapkan sehingga dapat meningkatkan Pendapatan Asli Daerah.

\section{Pengorganisasian}

Pengorganisasian diartikan sebagai proses kegiatan penyusunan struktur orgnisasi sesuai dengan tujuan-tujuan, sumber-sumber, dan lingkungannya. Melalui fungsi pengorganisasian, seluruh sumber daya yang di miliki oleh organisasi (manusia dan bukan manusia) akan diatur penggunanya secara efektif dan efesien untuk mencapai tujuan organisasi yang telah ditetapkan. Dalam hal ini Kepala Badan Pengelola Pajak Dan Retribusi Daerah Kota Kendari mempunyai tugas melaksanakan kewenangan Pemerintah Daerah di bidang keuangan, membawahi sekretaris dalam penyusunan dan pelaksanaan kordinasi perencanaan dan program Pendapatan Asli Daerah yang kemudian memberikan tugas kepada Bidang Pendaftaran Dan Pendataan, Bidang Penetapan dan Keberatan, dan Bidang penagihan dalam rangka pemungutan restribusi parkir.

Secara sederhana organisasi memerlukan sumber daya manusia yang bertugas melaksanakan pemungutan pajak dan mengawasi pelaksanaannya, dan dibutuhkan Standar Kerja agar pelaksanaan pemungutan pajak dapat terkordinir secara baik serta sarana dan prasarana yang menunjang pelaksanaan pemungutan retribusi parkir. Tiga unsur ini tidak berdiri sendiri-sendiri, akan tetapi saling kait atau saling berhubungan sehingga merupakan suatu kesatuan yang utuh dalam mencapai tujuan organisasi.

Dari wawancara, penulis melihat bahwa jumlah personil dilapangan dan kolektor retribusi parkir tidak seimbang dengan jumlah wajib pajak/jumlah tempat retribusi parkir yang tersebar di kawasan-kawasan Kota Kendari. Dengan demikian pemungutan retribusi parkir belum berjalan proporsional. Sehingga masih terjadi beberapa kendala dalam pemungutan pajak yang menyebabkan tidak tercapainya target yang ditentukan seperti yang terjadi pada tahun 2018. lebih lanjut penulis menyimpulkan bahwa untuk terlaksananya pemungutan retribusi secara efektif dibutuhkan kordinasi yang baik antara kolektor dan pengguna jasa parkir sehingga tidak saling menuding satu sama lain. Kerjasama yang baik dan sistem penagihan yang baik dilapangan perlu ditingkatkan agar tidak terjadi kesalah pahaman antara kolektor dan pengguna jasa parkir.

Terkait dengan standar kerja, sesuai hasil wawancara penulis menyimpulkan bahwa standar kerja kepada kolektor retribusi untuk melakukan penagihan dilapangan terhadap jatuh temponya retribusi parkir sering mengalami kendala seperti tidak disiplinnya pengguna jasa parkir sehingga para kolektor bentrok dengan pengguna jasa parkir dan kurangnya kesadaran pengguna jasa parkir dalam membayar retribusi yang menyebabkan terlambatnya penyetoran ke Kas Daerah. Demikian halnya dengan penggunaan sarana dan prasarana, penulis menyimpulkan bahwa sarana dan prasarana dalam melaksankan tugas di lapangan seperti pemasangan, pengawasan dan penagihan retribusi parkir di Kota Kendari sangat mempengaruhi pelaksanaan kerja dilapangan karena kolektor/staf harus berkeliling dalam melaksanakan tugasnya. Dengan adanya fasilitas sarana dan prasarana ini, dapat memberikan kenyamanan para pegawai dalam bekerja melaksanakan tugasnya.

\section{Pelaksanaan}

Pelaksanaan (Actuating) adalah fungsi manajemen yang berhubungan dengan kegiatan mengarahkan semua karyawan agar mau bekerjasama dan bekerja efektif secara efisien, agar terwujudnya tujuan dari organisasi, karyawan bahkan masyarakat. Dengan kata lain pelaksanaan (Actuating) adalah suatu usaha yang dilakukan 
untuk mencapai tujuan organisasi dengan berpedoman pada perencanaan (planning) dan usaha penggorganisasian (organizing).

Dari wawancara infroman, penulis menyimpulkan bahwa pelaksanaan berupa pengecekan dilapangan yang dilakukan oleh Bidang Pendaftaraan dan Pendataan hanya dilakukan sebulan sekali, pelaksanaan ini masih harus ditambah intensitasnya karena mengingat masih banyak penyimpangan parkir-parkir liar yang di pasang oleh masyarakat yang tidak mempunyai izin pemasangannya yang sangat mempengaruhi realisasi penerimaan pajak yang telah ditentukan agar pelaksanaan tugas berjalan dengan baik maka harus ada pembagian tugas yang baik agar dalam pelaksanaan pemungutan pajak dapat berjalan dengan optimal sehingga dapat terkordinasi secara baik. Lebih lanjut, penulis menyimpulkan bahwa untuk pelaksanaan penyelenggaraan retribusi parkir dibutuhkan kerjasama antara pihak pemerintah dan juga masyarakat sehingga dapat membantu mengoptimalkan pengelolaan retribusi parkir dalam meningkatkan Pendapatan Asli Daerah.

Upaya pengelolaan retribusi parkir yang dilakukan Badan Pengelola Pajak dan Retribusi Daerah Kota Kendari sudah cukup baik, namun dalam prosesnya nanti diharapkan adanya komitmen untuk menjalankan hal tersebut dengan maksimal, sehingga mampu meningkatkan kontribusi Pajak Parkir di Kota Kendari.

\section{Pengawasan}

Pengawasan dikatakan penting karena tanpa adanya pengawasan yang baik tentunya akan menghasilkan tujuan yang kurang memuaskan, baik bagi organisasinya itu sendiri maupun bagi para pekerjanya. Demikian halnya yang dilakukan Badan Pengelola Pajak dan Retribusi Daerah Kota Kendari dalam melakukan pengelolaan pajak restribus parkir. Sebab dalam pengelolaan ini tanpa adanya pengawasan maka akan mengalami kesulitan dalam mengukur tingkat keberhasilan dalam mengoptimalkan pelaksanaan pemungutan retribusi parkir di Kota Kendari.

Adapun jenis pengawasan yang dilakukan oleh Badan Pengelola Pajak dan Retribusi Daerah Kota Kendari dalam pengelolaan retribusi parkir yaitu pengawasan secara langsung dan pengawasan tidak langsung.

Dalam pengawasan langsung, dilakukan dengan peninjauan dan pemeriksaan atas pelaksanaan kegiatan di lapangan yang berhubungan dengan pemungutan retribusi parkir dan peninjauan letak pemasangan parkir sesuai dengan aturan yang telah ditetapkan.

Dari wawancara di atas penulis menyimpulkan bahwa sanksi yang tegas akan diberikan kepada para pegawai yang melakukan kelalaian dalam pemungutan pajak dan juga sanksi yang diberikan kepada wajib retribusi parkir yang telah melakukan kesalahan. Proses pengawasanyang dilakukan oleh Badan Pengelola Pajak dan Retribusi Daerah Kota Kendari seperti melakukan pemantauan di lapangan dan menyesuaikan dengan data yang telah diperoleh, kemudian jika terjadi adanya penyimpangan maka telah di atur dalam Peraturan Retribusi Parkir mengenai pengendalian dan pengawasan pajak parkir dinyatakan bahwa Tim Penertiban Pajak dan Retribusi Daerah yang telah dibentuk berwenang melakukan penutupan atau pembongkaran terhadap jenis-jenis pemasangan parkir sebagai berikut:

1) Pemasangan parkir yang sudah berakhir masa berlakunya dan tidak diajukan perpanjangan ijin;

2) Pemasangan parkir yang tidak memiliki ijin;

3) Pemasangan tempat parkir yang tidak sesuai dengan ijin yang diberikan;

4) Pemasangan parkir yang melanggar dan telah melalui mekanisme yang telah ditetapkan. 
Vol.1 No.4. Januari 2019. pp.18-31. Copyright@2019 PUBLICUHO Faculty of Social and Political Sciences Halu Oleo University, Kendari, Southeast Sulawesi, Indonesia. ISSN: 2460-058X | e-ISSN: 2621-1351. Open Access at: http://ojs.uho.ac.id/index.php/PUBLICUHO

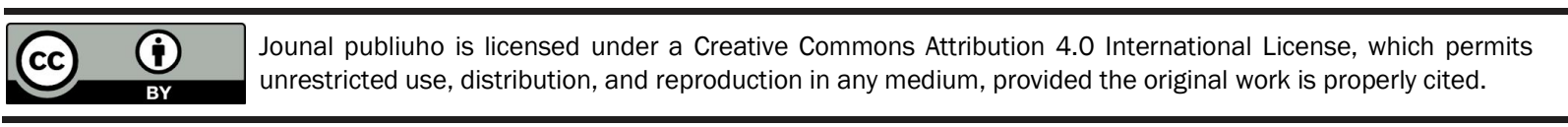

Dalam pengawasan tidak langsung, sesuai hasil wawancara penulis menyimpulkan bahwa pengawasan yang dilakukan Badan Pengelola Pajak dan Retribusi Daerah Kota Kendari hanya mengandalkan laporan-laporan semata pada pengelolaan retribusi parkir, maka dari itu perlu melakukan pengawasan yang rutin kepada para pengelola retribusi parkir guna melihat secara langsung pelaksanaan pemungutan retribusi parkir dan menilai apakah pelaksanaan retribusi parkir telah berjalan secara efektif dan telah sesuai dengan apa yang telah direncanakan dan jangan hanya berfokus pada pengawasan laporan keuangan yang telah masuk.

\section{Konstribusi Pengelolaan Retribusi Parkir}

Dalam pelaksanaan pemungutan Retribusi parkir di Kota Kendari masih mengalami banyak hambatan, baik hambatan dari dalam (kolektor pajak/staf di lapangan) maupun dari luar yakni masyarakat atau wajib pajak. Untuk mengoptimlakan pemungutan retribusi parkir di kota Kendari maka pengelolaan pajak restribusi parkir harus berjalan secara efektif dan efisien, karena dengan pengelolaan yang baik berupa perencanaan, pengorganisasian, pelaksanaan serta pengawasan akan menghasilkan tujuan yang diinginkan seperti realisasi pencapaian target yang telah ditentukan.

Retribusi parkir merupakan salah satu pajak daerah yang sangat berperan penting dalam meningkatkan Pendapatan Asli Daerah Kota Kendari. Penerimaan retribusi parkir yang di kelolah oleh Badan Pengelola Pajak Dan Retribusi Daerah Kota Kendari sejak tahun 2014 sampai dengan 2018 menunjukkan peningkatan, berikut ini data tabel realisasi retribusi parkir :

Tabel 4. Target Realisasi Retribusi parkir 3 Tahun Terakhir Dari 2016-2018

\begin{tabular}{|l|c|l|l|l|}
\hline No & Tahun & \multicolumn{1}{|c|}{ Target } & \multicolumn{1}{c|}{ Realisasi } & \multicolumn{1}{c|}{$\%$} \\
\hline l. & 2016 & Rp. $1.565 .000 .000,00$ & Rp. $1.584 .447 .925,00$ & 101,24 \\
\hline 2. & 2017 & Rp. $2.065 .000 .000,00$ & Rp. $1.674 .071 .450,00$ & 81,06 \\
\hline 3. & 2018 & Rp. $1.970 .000 .000,00$ & Rp. $1.978 .512 .450,00$ & 100,43 \\
\hline
\end{tabular}

Sumber: Badan Pengelola Pajak dan Retribusi Daerah Kota Kendari 2019

Selanjutnya penulis menyajikan data tentang perkembangan persentasi antara terget dan realisasi retribusi parkir dari tahun 2016-2018. Untuk lebih jelasnya dapat dilihat pada bagan 1 berikut :

Gambar 2. Grafik Persentasi Target dan Realisasi Retribusi Parkir 2016-2018

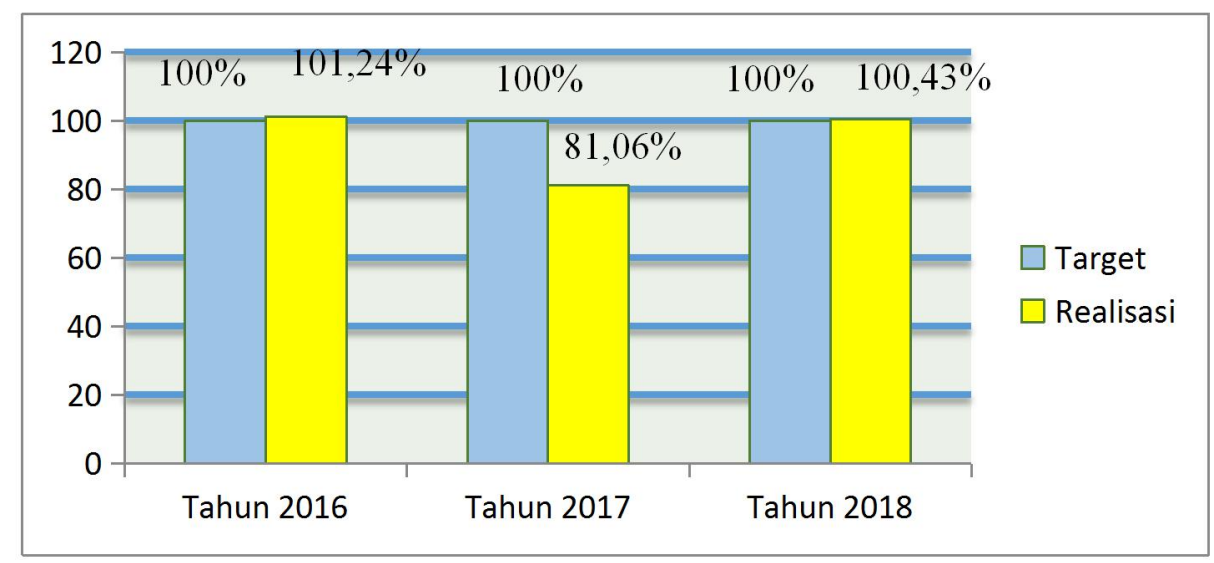

Sumber: Badan Pengelola Pajak dan Retribusi Daerah Kota Kendari 2019

Berdasarkan data diatas penulis menyimpulkan bahwa persentasi realisasi pencapaian target retribusi parkir setiap tahunnya mengalami fluktuasi. Terlihat pada tahun 2017 mengalami penurunan dan target tidak tercapai seperti pada tahun lainnya. Selanjutnya mengalami penaikan kembali pada tahun 2018. 


\section{KESIMPULAN}

Berdasarkan uraian dan pembahasan di atas maka penulis menarik simpulan penelitian bahwa Berdasarkan hasil penelitian, pengelolaan biaya parkir yang telah dilakukan selama ini sudah cukup baik, dapat dilihat dari persentase antara target dan realisasi retribusi parkir dari 2016-2018 yang mengalami fluktuasi dan pada tahun 2017 dilakukan tidak mencapai target yang ditetapkan, dan 3 (tiga) tahun terakhir kontribusi biaya parkir ini terhadap pendapatan asli daerah sangat kecil. Ini karena masih banyak kendala yang dialami oleh Badan Pengelolaan Pajak dan Retribusi Daerah di Kendari dalam mengelola biaya parkir. Dalam proses perencanaan telah berjalan dengan baik dapat dilihat dalam menentukan target retribusi parkir per tahun yang selalu mengacu pada hasil evaluasi pencapaian target pada tahun sebelumnya dan melihat potensi di lapangan. Pengorganisasian masih belum efektif, hal ini bisa dilihat dari standar kerja petugas parkir masih mengalami kendala dalam jumlah personel. Dari upaya implementasi, masih belum efektif dalam memungut pajak parkir, seperti pemberian izin parkir, masih ada sebagian yang melakukan pemasangan tanpa membuat izin terlebih dahulu dan kurang kesadaran wajib pajak tentang pentingnya membayar pajak yang mana dasar untuk Pengembangan Kota Kendari. Hanya indikator pengawasan yang dilakukan oleh atasan kepada bawahan yang efektif, seperti pemantauan yang dilakukan untuk mengevaluasi pekerjaan yang dimaksimalkan, sehingga tidak memberikan peluang bagi individu di lapangan untuk melakukan penipuan. Namun pengawasan masyarakat masih belum efektif karena masih banyak tempat parkir ilegal tanpa izin pemasangan.

\section{DAFTAR PUSTAKA}

Amirullah. 2015. Pengantar Manajemen. Jakarta: Mitra Wacana Media

Arikunto, Suharsimi. 1988. Pengelolaan kelas dan siswa, Jakarta : CV. Rajawali

Bratakusumah, Deddy Supriyadi\& Solihin, Dadang. 2001. Otonomi Penyelenggaraan Pemerintah Daerah, Jakarta: Gramedia Pustaka Utama

Darise, Nurlan. 2009. Pengelolaan Keuangan Daerah, Edisi 2. Jakarta, Indeks

Departemen Pendidikan dan Kebudayaan, 1999. Kamus besar Indonesia, Edisi II Jakarta : Balai Pustaka, 1999

Direktorat Jendral Pajak, Undang-Undang Nomor 28 Tahun 2007 Tentang Perubahan Ketiga atas UndangUndang Nomor 6 Tahun 1983 Tentang Ketentuan Umum dan Tata Cara Perpajakan.

Direktorat Perpajakan. Undang-Undang Nomor 34 Tahun 2000 Tentang Pajak Daerah dan Retribusi Daerah

Follet, Marry Parker. 2005. Manajemen. Jakarta: Indeks

Kartasasmita, Ginandjar. 1996. Pembangunan Untuk Rakyat Memadukan Pertumbuhan dan Pemerataan, Jakarta: PT. Pusaka Cidesindo

KBBI, Kamus Besar Bahasa Indonesia (KBBI) http://kbbi.web.id/pusat. Online: diakses 25 Februari 2019

Kurniawan, Panca. 2006, Pajak Daerah dan Retribusi Daerah di Indonesia, Malang, Bayumedia Publishing.

Manulang, M. 1990. Dasar-Dasar Manajemen, (Jakarta : Ghalia Indonesi

Martoyo, Susilo 1998. Pengetahuan Dasar Manajemen Dan Kepemimpinan, Yogyakarta : BPFE 
Vol.1 No.4. Januari 2019. pp.18-31. Copyright@2019 PUBLICUHO Faculty of Social and Political Sciences Halu Oleo University, Kendari, Southeast Sulawesi, Indonesia. ISSN: 2460-058X | e-ISSN: 2621-1351. Open Access at: http://ojs.uho.ac.id/index.php/PUBLICUHO

(1) Jounal publiuho is licensed under a Creative Commons Attribution 4.0 International License, which permits BY unrestricted use, distribution, and reproduction in any medium, provided the original work is properly cited.

Miles \& Huberman. 2000. Analisis Data Kualitatif. Jakarta: UI Press.

Peraturan Menteri Dalam Negeri Nomor 21 Tahun 2011. Tentang Perubahan Kedua Atas Peraturan Menteri Dalam Negeri Nomor 13 Tahun 2006. Tentang Pedoman Pengelolaan Keuangan Daerah.

Peraturan Pemerintah Nomor 97 Tahun 2012, Tentang Retribusi Pengendalian Lalu Lintas dan Retribusi Perpanjangan Izin Tenaga Kerja Asing

Peraturan Pemerintah Republik Indonesia. Nomor 66 tahun 2001. Tentang. Retribusi daerah

Siahaan, Marihot. 2010, Pajak Daerah dan Retribusi Daerah, Jakarta, Raja Grafindo Persada.

Soemitro, Rochmat. 2011. Asaz dan Dasar Perpajakan. Bandung, Rafika Aditama

Sugiyono. 2013. Metode Penelitian Pendidikan Pendekatan Kuantitatit, Kualitatit, dan R\&D. Bandung: Alfabeta.

Syafri, Sofyan. Manajemen kontemporer, Jakarta : PT. Raja Grafindo Persada, 1996

Undang Undang Nomor 28 Tahun 2009 Tentang Pajak Daerah dan Retribusi Daerah

UU No.33 tahun 2004 tentang Perimbangan Keuangan Antara Pemerintah Pusat dan Pemerintah Daerah

Yani, Ahmad. 2008. Hubungan Keuangan Daerah antara Pemerintah Pusat dan Daerah di Indonesia, Jakarta:

Rajawali Pers. 